\title{
Notes on the vocalizations of Sunda Warbler (Seicercus grammiceps)
}

\section{Peter Boesman}

In the following we briefly analyze and compare voice of the two races of Sunda Warbler (Seicercus grammiceps). We also try to quantify the extent of any vocal differences using the criteria proposed by Tobias et al. (2010), as a support for taxonomic review.

We have made use of sound recordings available on-line from Xeno Canto (XC) and Macaulay Library (ML).

A comparison of song, illustrated with sonograms:

\section{Sumatra (sumatrensis)}

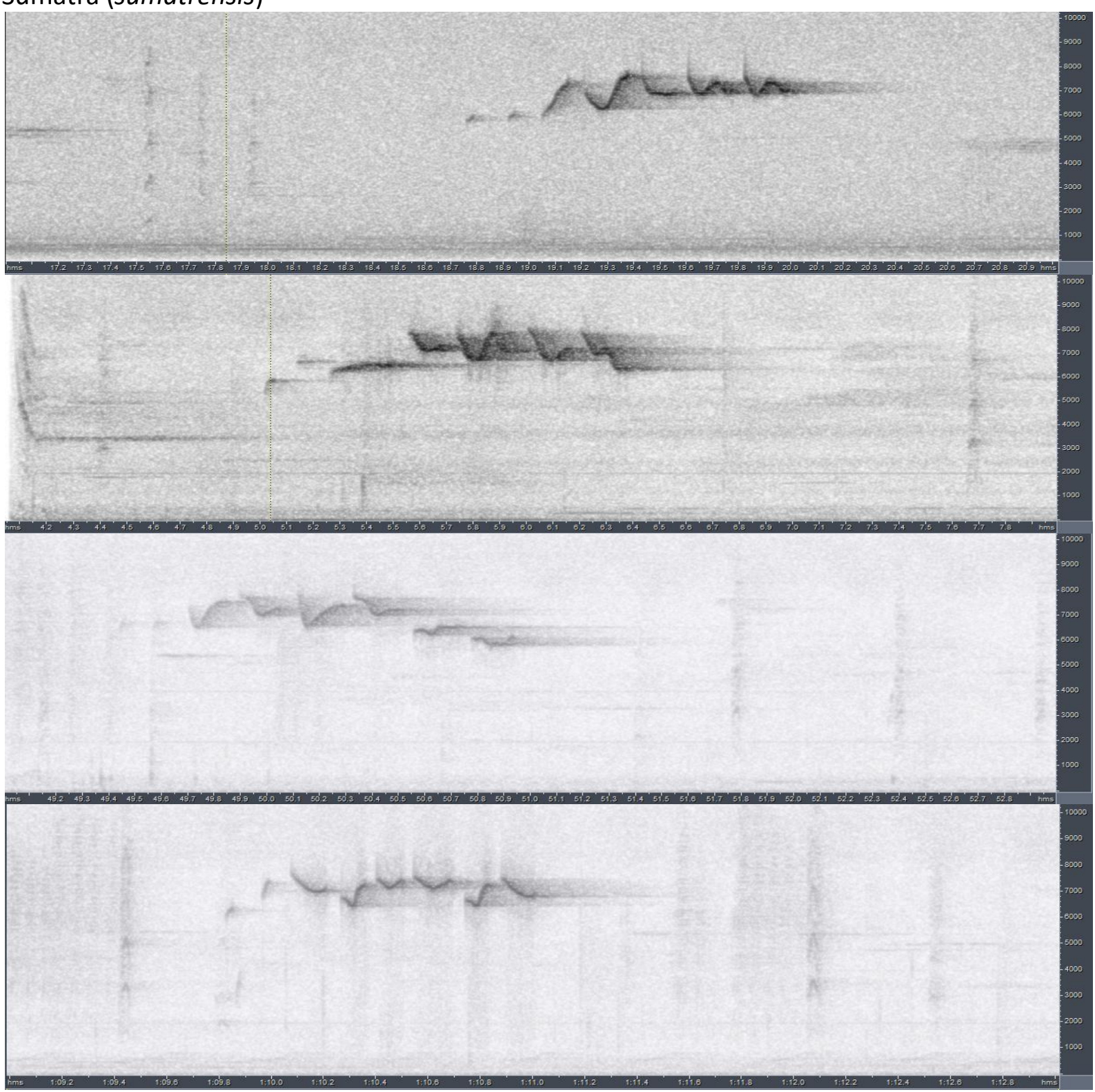




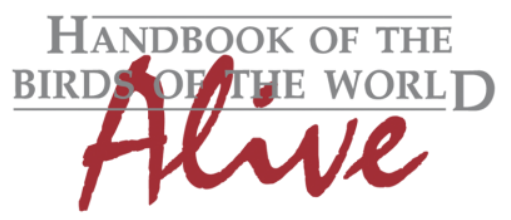

\section{ORNITHOLOGICAL NOTES}

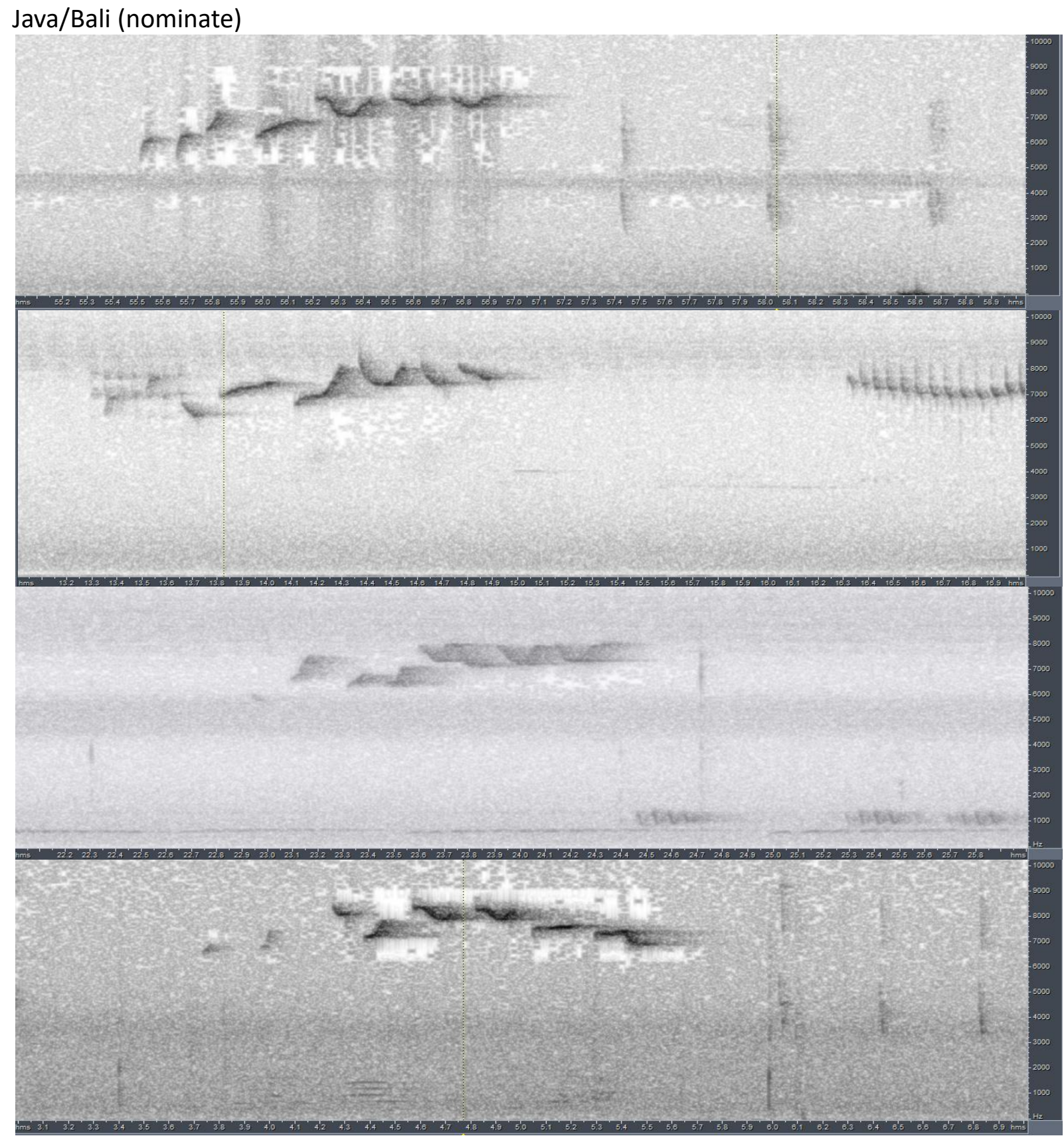

Song of both races is a short high-pitched phrase of some $5-8$ notes (duration $c 1.5 \mathrm{~s}$ ). Notes have a rather narrow frequency range and are all rather similar-shaped.

Structure and basic sound parameters are about identical for both races. We typically give priority to song for quantification of vocal difference and scoring, which in this case would lead to a zero score. At the other hand, on Sumatra two more closely related species occur: S. montis and S. castaneiceps which have a song which is also very similar or identical !

We therefore also have a look at the calls, as these may play a more important role here (compare e.g. with Zimmerius in the New World). 


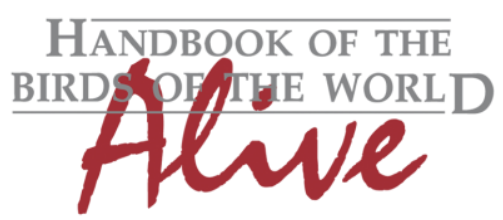

\section{ORNITHOLOGICAL NOTES}

An overview of call notes per taxon, including montis and castaneiceps.

\section{sumatrensis}

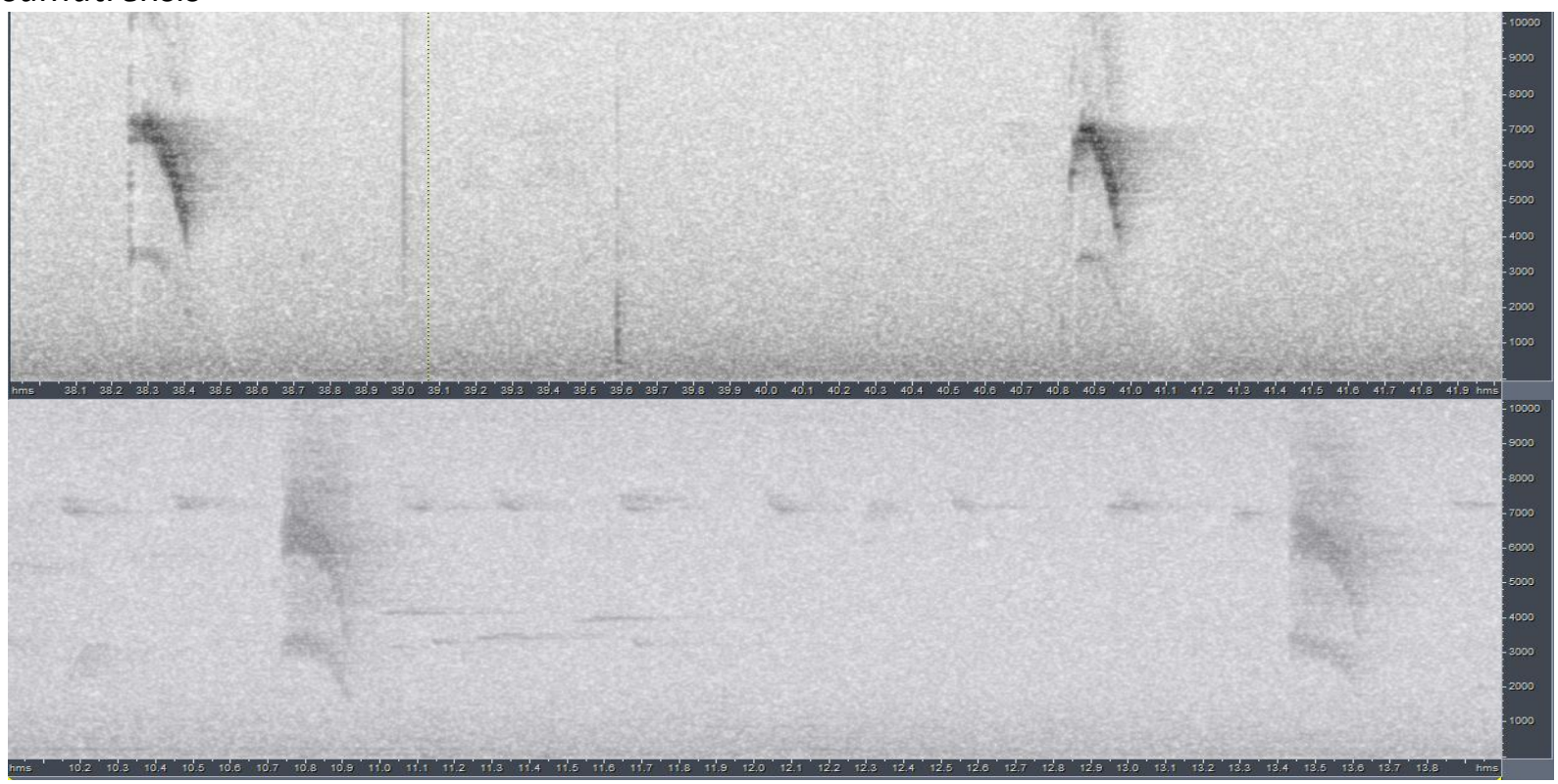

grammiceps

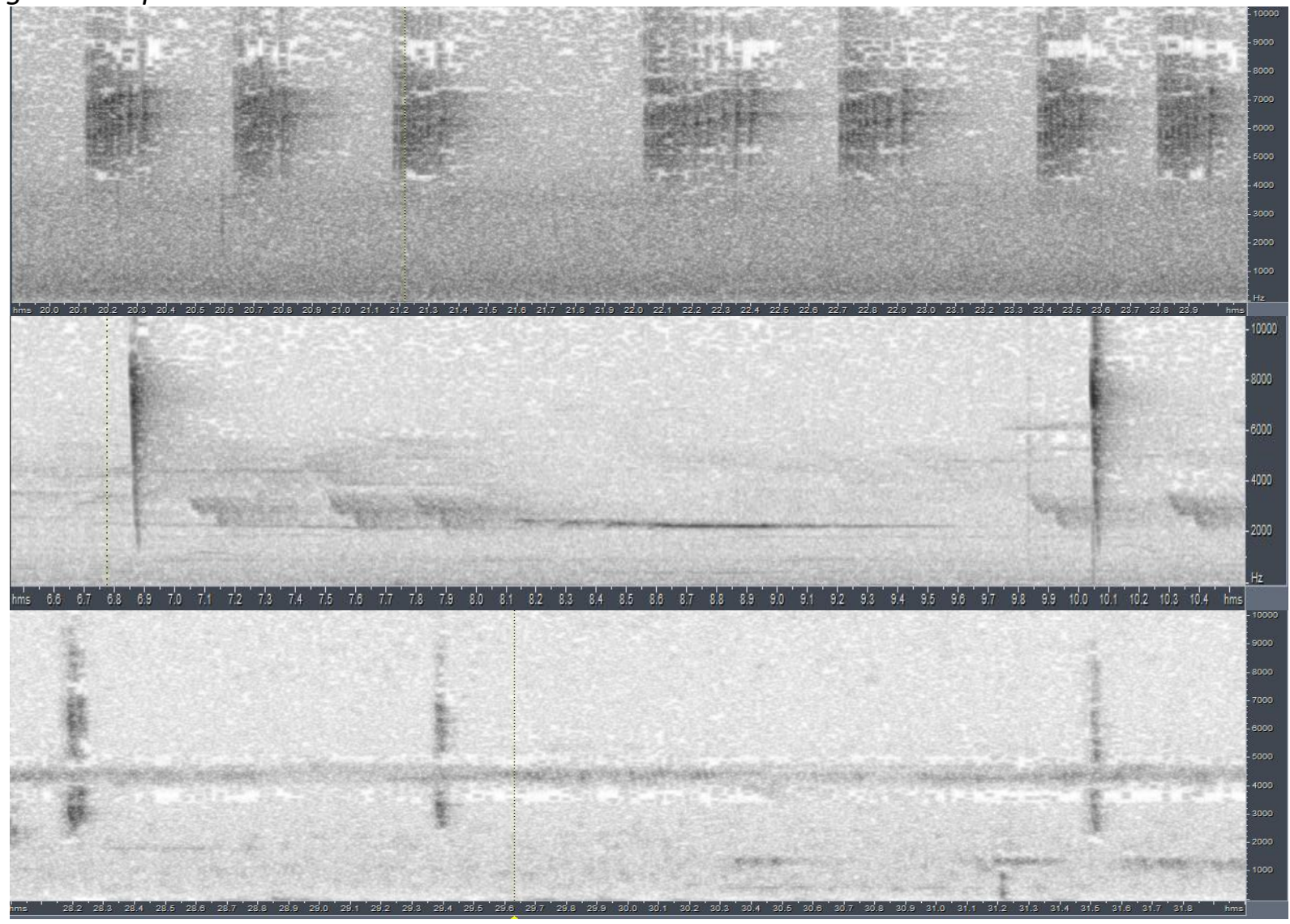




\section{HANDBOOK OF THE \\ BIRDSPFTHE WORLD ORNITHOLOGICAL NOTES}

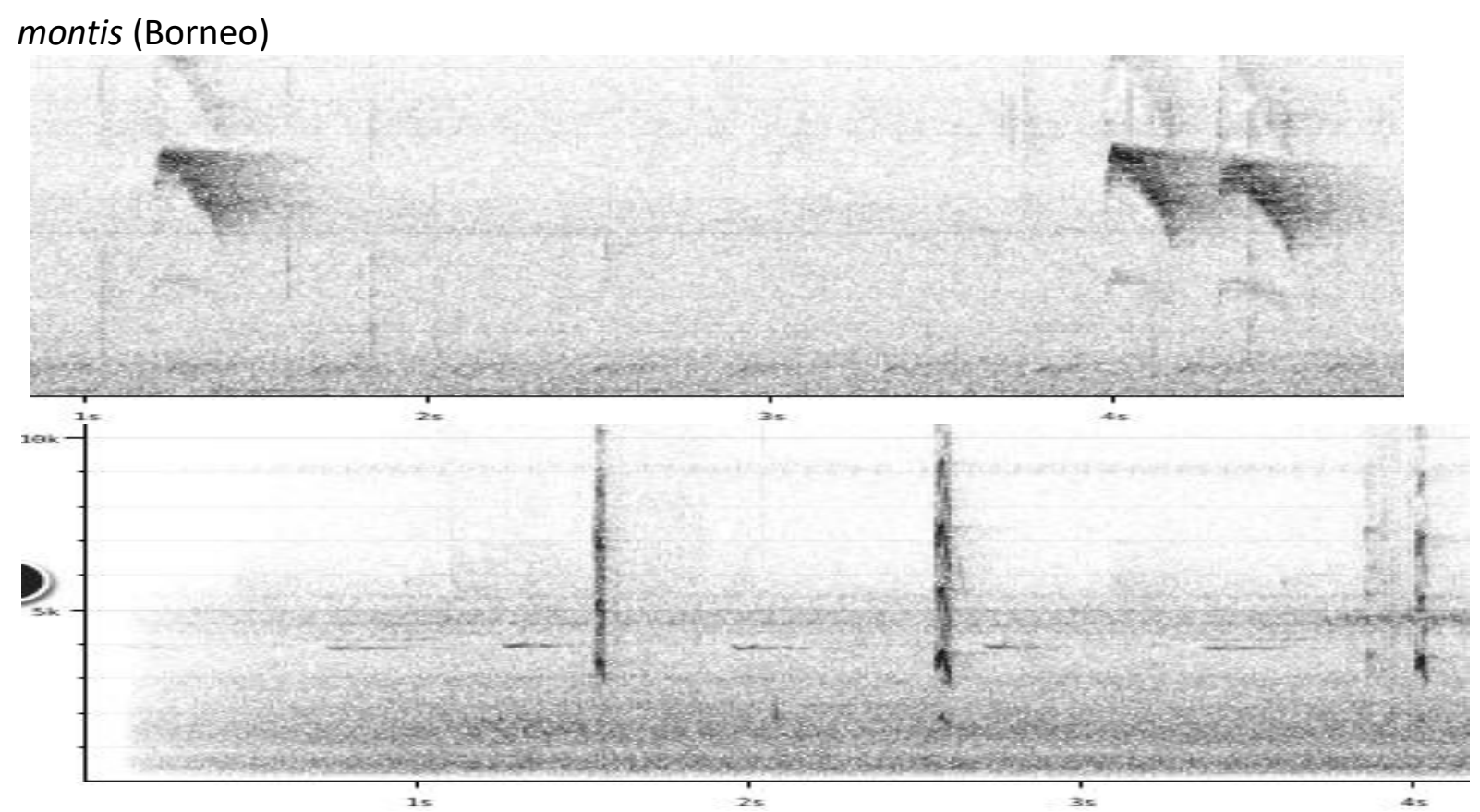

Flores

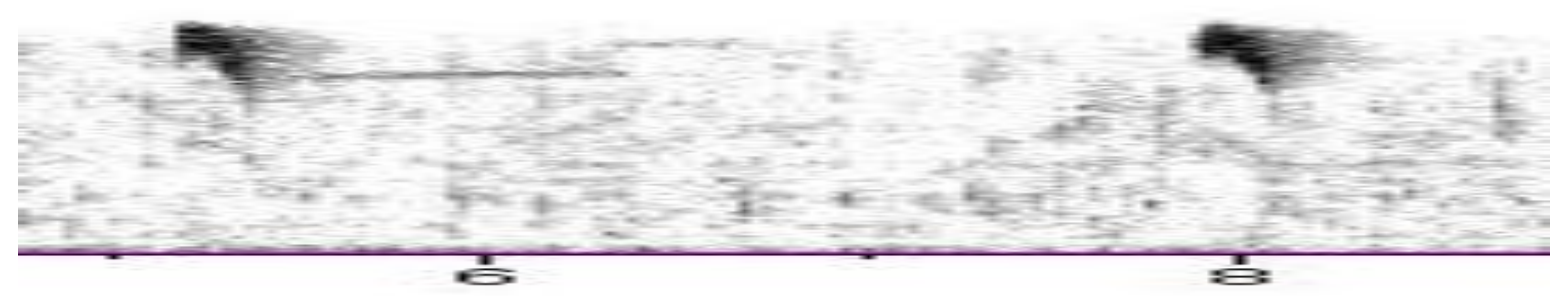

\section{castaniceps}

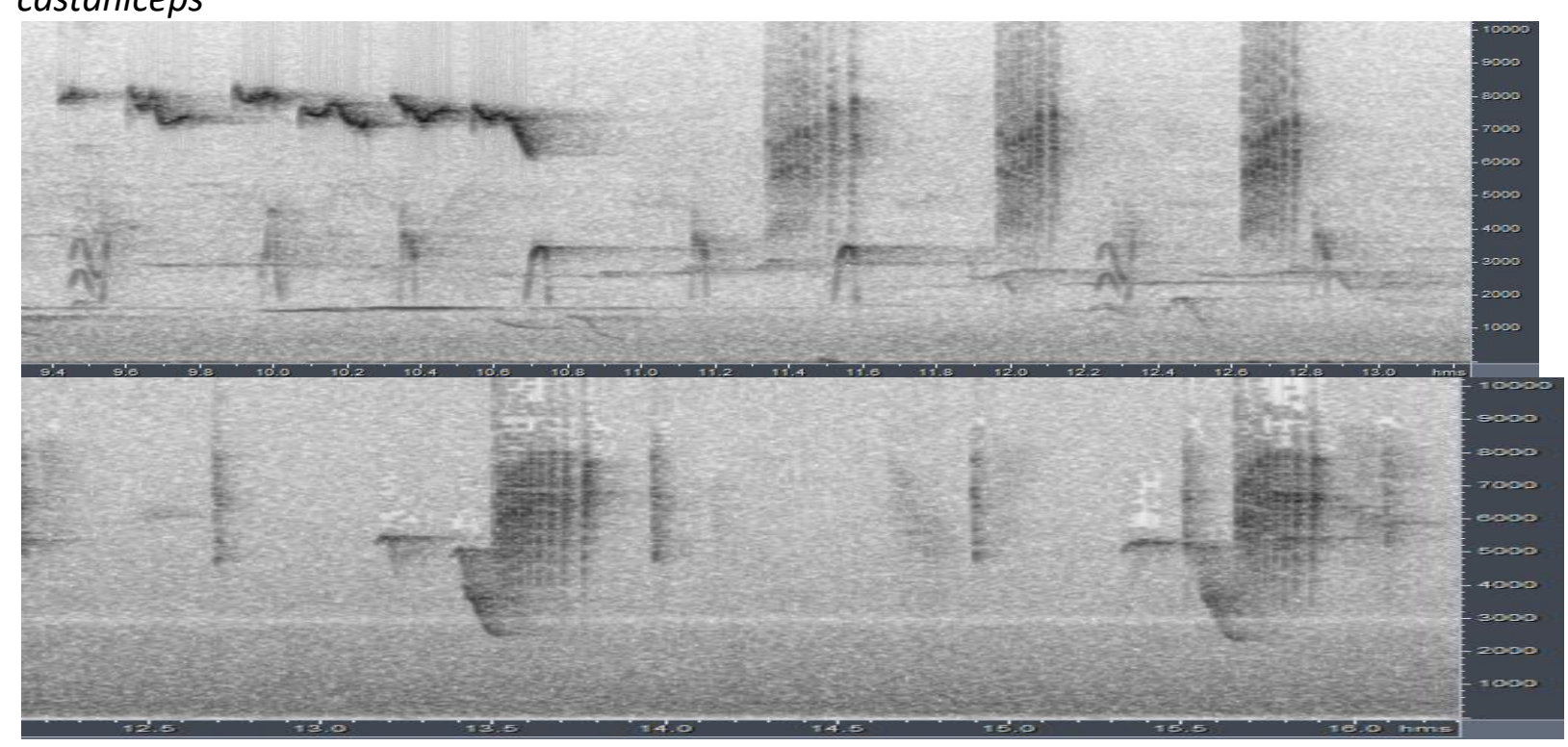



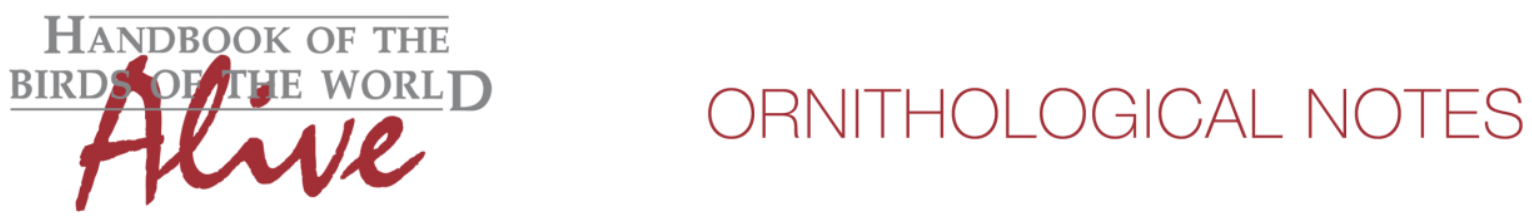

There seem to be three call types:

1. a short single nasal note

2. a short high-pitched rattle

3. a buzzy high-pitched overslurred note

All three call types are significantly different, each pair-wise comparison reaching a score of about 4 (based on length, \# of notes, pitch,...).

From the available recordings, we deduct which taxon utters which call types:

$\begin{array}{llll}\text { sumatrensis } & \text { call 1 } & \text { call 2 } & \text { call 3 } \\ \text { grammiceps } & & & \mathrm{x} \\ \text { montis } & \mathrm{x} & \mathrm{x} & \\ \text { castaniceps } & \mathrm{x} & & \mathrm{x} \\ & & \mathrm{x} & \end{array}$

Lack of recordings not necessarily means lack of vocalization (!), but it would seem that:

* none of the taxa has a unique call

* montis and castaniceps (which co-occur in several regions) seem to have developed different calls.

* grammiceps which is the only one on Java/Bali seems not to have developed the highpitched buzzy call, while sumatrensis which co-occurs with montis shares the buzzy call

More recordings are definitely needed to confirm differences in calls. At present it would seem that sumatrensis and grammiceps do not share call types.

This note was finalized on 23rd June 2016, using sound recordings available on-line at that moment. We would like to thank in particular the many sound recordists who placed their recordings for these species on XC and ML.

\section{References}

Tobias, J.A., Seddon, N., Spottiswoode, C.N., Pilgrim, J.D., Fishpool, L.D.C. \& Collar, N.J. (2010). Quantitative criteria for species delimitation. Ibis 152(4): 724-746.

\section{Recommended citation}

Boesman, P. (2016). Notes on the vocalizations of Sunda Warbler (Seicercus grammiceps). HBW Alive Ornithological Note 423. In: Handbook of the Birds of the World Alive. Lynx Edicions, Barcelona. (retrieved from http://www.hbw.com/node/1254384 on 7 December 2016). 